\title{
SISTEM PAKAR BACKWARD CHAINING UNTUK PEMILIHAN ALAT KONTRASEPSI YANG COCOK BERBASIS ANDROID
}

\author{
Lido Sabda Lesmana \\ Dosen Sistem Informasi Universitas Putera Batam \\ Jl. R. Soeprapto - Muka Kuning - Batam \\ Lidosabdalesmana11603@gmail.com \\ Submitted: 10-10-2017, Reviewed: 26-10-2017, Accepted 03-11-2017 \\ http://dx.doi.org/10.22202/jei.2017.v4i1.2533
}

\begin{abstract}
ABSTRAK
Untuk program keluarga berencana juga menjadi salah satu tugas dan tanggung jawab bagi seorang Dokter ataupun bidan memberikan solusi yang tepat untuk pasien agar mendapatkan langkah ataupun cara dalam program kegiatan keluarga berencana tersebut. Jika dilihat dari hasil peringkat jumlah kepadatan penduduk menurut CIA World Factbook pada tahun 2004, Indonesia menempati jumlah penduduk yang terbanyak nomor 4 didunia dengan jumlah penduduknya adalah 238.452.952 jiwa. Sehingga melihat kondisi tersebut Keluarga berencana bertujuan memiliki dua anak cukup adalah sebuah program pemerintah Indonesia yang sudah bertahun-tahun di jalankan. Akan tetapi yang sering jadi kendala adalah untuk pemilihan langkah untuk menjalankan program tersebut seperti Kondom, Pil KB, Suntikan KB, AKDR (Alat Kontrasepsi Dalam Rahim) dan sebagainya. Dengan Bantuan program Android yang ada pada smart phone akan membantu masyarakat dalam mendapatkan informasi secara online kapanpun dan dimanapun berada tentang pemanfaatan dan kendala yang dihadapi dalam menjalankan program Keluarga Berencana tersebut.
\end{abstract}

Kata kunci: Keluarga Berencana, Alat Kontrasepsi, Backward Chaining, Smart phone 


\begin{abstract}
Family planning program is also one of duty and responsibility for a doctor or midwife provide the right solution for patient to get step or way in program of activity of family planning. If viewed from the rankings of the number of population density according to CIA World Factbook in 2004, Indonesia occupies the number of population most number 4 in the world with a population of 238,452,952 people. So look at the condition Family planning to aim to have two children enough is an Indonesian government program that has for years on the run. However, the most common obstacle is for the selection of steps to run the program such as Condoms, Birth Control Pills, KB Injections, IUD (Intrauterine Device) and so on. With the help of existing Android program on the smart phone will help people in getting information online whenever and wherever about the utilization and constraints faced in running the family planning program.
\end{abstract}

Keywords : Family Planning, Contraception, Backward Chaining, Smart Phone

\section{PENDAHULUAN}

Untuk mendapatkan keturunan adalah harapan dan keinginan bagi makhluk yang mempunyai pasangan didunia ini termasuk manusia makhluk Tuhan yang diciptakan secara sempurna dibandingkan dengan makhluk Ciptaan Tuhan yang lainnya. Anak merupakan titipan dari sang pencipta untuk melanjutkan kehidupan orang tua ke masa yang akan datang.

Kebijakan pemerintah yang tertuang pada peraturan pemerintah nomor 87 tahun 2014 tentang perkembangan kependudukan dan pembangunan keluarga, keluarga berencana, dan sistem informasi keluarga. Pada BAB I pasal 1 Kependudukan adalah hal ihwal yang berkaitan dengan jumlah, struktur, pertumbuhan, persebaran, mobilitas, penyebaran, kualitas, dan kondisi kesejahteraan yang menyangkut politik, ekonomi, sosial budaya, agama serta lingkungan penduduk setempat (Republik Indonesia, 2014). Sehingga untuk menambah keturunan juga harus mempertimbangkan beberapa hal seperti yang tertuang pada peraturan pemerintah diatas untuk meningkatkan jumlah penduduk di Indonesia. 
Untuk kecerdasan buatan banyak metode yang bisa dimanfaatkan, baik dibidang elektronik, penyakit dan sebagainya. Salah satunya adalah kecerdasan buatan (Expert System) yang bisa dijadikan sebagai salah satu cara untuk melakukan pemilihan alat Kontrasepsi dibidang Kesehatan. Seperti yang dijelaskan dalam penelitian (Soltan, Rashad, \& ElDesouky, 2013) One of the most important areas of Artificial Intelligence (AI) is an Expert system. The proposed system for dealing with the problem of heart diseases diagnosis and treatment is an expert system. Expert System (ES) is widely used in many areas and it has many applications. Most important fields area of expert system is the medicine and it use in detection, diagnosing symptoms and treatment diseases. Dengan adanya program keluarga berencana tersebut kita bisa menunjang program pemerintah untuk mengatur tingkat kelahiran anak dan mengatur jarak umur dari anak pertama sampai program untuk anak berikutnya seperti yang telah diatur pada BAB I Pasal 2 point $\mathrm{c}$ dengan isi meningkatkan upaya mengatur kelahiran anak, jarak, usia ideal melahirkan, mengatur kehamilan, melalui promosi, perlindungan dan bantuan sesuai dengan hak reproduksi untuk mewujudkan keluarga berkualitas (Republik Indonesia, 2014).
Berdasarkan dari berbagai permasalahan yang dihadapi oleh masyarakat tersebut maka akan dirancang sebuah program yang mengimbangi perkembangan teknologi di bidang elektronik saat ini seperti Smart Phone. Bantuan program Android yang ada pada smart phone akan membantu masyarakat dalam mendapatkan informasi secara online kapanpun dan dimanapun berada tentang pemanfaatan dan kendala yang dihadapi dalam menjalankan program Keluarga Berencana tersebut. Dengan memberikan solusi dibidang teknologi informasi berbasis Smart Phone, akan membantu pemerintah dalam mengendalikan jumlah kependudukan di Indonesia seperti yang dituangkan dalam peraturan pemerintah dalam pasal 55 No.87 tentang pengolahan data dan Informasi Keluarga yang berbunyi "Pengolahan Data dan Informasi Keluarga sebagaimana dimaksud pada ayat (1) dan ayat (2) dilakukan secara berkala dalam rangka pengendalian pelaksanaan program pengendalian penduduk dan keluarga berencana” (Republik Indonesia, 2014).

\section{TINJAUAN PUSTAKA}

\subsection{Sistem Pakar}

Secara umum Sistem Pakar adalah keahlian atau kepakaran seseorang yang dimanfaatkan untuk memberikan solusi 
dari masalah yang dihadapi dan diimplementasikan kedalam sebuah komputer. Sehingga komputer dapat bekerja selayaknya seorang pakar dalam menyelesaikan sebuah masalah. Sedangkan Menurut (Setyawan \& Isa, 2013) Sistem pakar secara umum adalah sistem yang berusaha mengadopsi pengetahuan pakar ke komputer, agar dapat menyelesaikan masalah seperti yang dilakukan oleh para ahli.

Sistem yang menggabungkan pengetahuan dan penelusuran data untuk memecahkan masalah yang secara normal memerlukan keahlian manusia. Tujuan pengembangan sistem pakar sebenarnya bukan untuk menggantikan peran manusia, tetapi untuk mensubstitusikan pengetahuan manusia ke dalam betuk sistem, sehingga dapat digunakan oleh banyak orang (Andi, 2009) dan Expert System - is a computer program that employs the knowledge of human experts to solve problems that usually would require human intelligence (Asabere \& Enguah, 2012).

Sistem pakar merupakan cabang dari Artificial Intelligence (AI) yang cukup tua karena sistem ini telah mulai dikembangkan pada pertengahan tahun 1960. Sistem pakar yang muncul pertama kali adalah General-purpose problem solver (GPS) yang dikembangkan oleh Newl dan Simon. Sampai saat ini sudah banyak sistem pakar yang dibuat, seperti MYCIN, DENDRAL, XCON \& XSEL, SOPHIE, Prospector, FOLIO, DELTA, dan sebagainya (Rohman \& Fauzijah, 2008).

\subsubsection{Ciri-Ciri Sistem Pakar}

Sebuah sistem memiliki beberapa kriteria ataupun ciri-ciri tersendiri, maka Ciri - ciri yang bisa diuraikan dari sistem pakar ini adalah :

a. Terbatas pada domain keahlian tertentu

b. Dapat memberikan penalaran untuk data-data yang tidak pasti

c. Dapat mengemukakan rangkaian alasan-alasan yang diberikannya dengan cara yang dapat dipahami

d. Berdasarkan pada kaidah / rule tertentu

e. Dirancang untuk dapat dikembangkan secara bertahap

f. Pengetahuan dan mekanisme inferensi jelas terpisah

g. Keluarannya bersifat anjuran

h. Sistem dapat mengaktifkan kaidah secara searah yang sesuai, dituntun oleh dialog dengan pemakai

\subsubsection{Konsep Dasr Sistem Pakar}

Sistem pakar harus mengandung : keahlian, ahli, pengalihan keahlian, inferensi, aturan dan kemampuan 
menjelaskan (Setyawan \& Isa, 2013). Keahlian adalah suatu kelebihan penguasan pengetahuan di bidang tertentu yang diperoleh dari pelatihan, membaca atau pengalaman. Expert systems consist of two main parts: the knowledge base and the inference engine. The knowledge base contains the expert system knowledge (Asabere \& Enguah, 2012). Bentuk pengetahuan :

$$
\begin{aligned}
\checkmark & \text { fakta-fakta pada lingkup } \\
& \text { permasalahan tertentu } \\
\checkmark & \text { teori-teori pada lingkup masalah } \\
& \text { tertentu } \\
\checkmark & \text { prosedur-prosedur berkenaan } \\
& \text { dengan lingkup masalah tertentu } \\
\checkmark & \text { strategi-strategi global untuk } \\
& \text { menyelesaikan masalah } \\
\checkmark & \text { meta-knowledge (pengetahuan } \\
& \text { tentang pengetahuan). }
\end{aligned}
$$

\subsubsection{Jenis-jenis Sistem Pakar}

a. Forward Chaining (Runut Maju)

Forward chaining merupakan proses perunutan yang dimulai dengan menampilkan kum-pulan data atau fakta yang meyakinkan menuju konklusi akhir.

b. Backward Chaining (Runut Balik)

Backward chaining atau runut balik merupakan proses perunutuan yang arahnya kebalikan dari runut maju. Proses penalaran runut balik dimulai dari goal atau tujuan kemudian balik ke jalur yang akan mengarahkan ke goal tersebut, mencari bukti-bukti bahwa bagian kondisi terpenuhi.

\subsection{Alat Kontrasepsi}

Kontrasepsi berasal dari kata kontra berarti 'mencegah' atau 'melawan' dan konsepsi berarti pertemuan antara sel telur yang matang dan sel sperma yang mengakibatkan kehamilan. Maksud dari kontrasepsi adalah menghindari / mencegah terjadinya kehamilan sebagai akibat dari pertemuan antara sel telur yang matang dengan sperma tersebut (Kamaludin, 2012). Kontrasepsi adalah suatu alat, obat atau cara yang digunakan untuk mencegah terjadinya konsepsi atau pertemuan antara sel telur dengan sel jantan (sperma) di dalam kandungan/rahim (Tentua, 2010). Secara umum definisi ini sering digunakan, tetapi secara khusus tentu akan melibatkan beberapa macam factor dalam proses pencegahan ini. Untuk memahami keadaan tersebut maka akan diuraikan secara singkat dan padat beberapa jenis kontrasepsi yang sering digunakan di Indonesia dan sangat perlu dipahami oleh petugas/provider dalam memberikan konsultasi lapangan mengenai Keluarga Berencana. (Tentua, 2010):

a. Kondom

Sarung karet tipis penutup penis yang menampung cairan sperma pada saat pria ejakulasi.

b. Pil KB 
Hormon yang mengandung estrogen dan progesterone atau progesterone saja yang diminum setiap hari selama 21 hari atau 28 hari.

c. Suntikan $\mathrm{KB}$

Hormon progesteron yang disuntikkan ke bokong/otot panggul lengan atas setiap 3 bulan atau hormon estrogen yang disuntikkan setiap 1 bulan sekali.

d. AKBK (Alat Kontrasepsi Bawah Kulit) / Susuk

1 atau 6 kapsul (seperti korek api) yang dimasukkan ke bawah kulit lengan atas secara perlahan melepaskan hormon progesterone selama 3 atau 5 tahun.

e. AKDR (Alat Kontrasepsi Dalam Rahim)

Alat kontrasepsi yang dimasukkan ke dalam rahim yang bentuknya bermacammacam, terbuat dari plastic, plastic yang dililit tembaga atau tembaga bercampur perak yang dapat berisi hormonedan waktu penggunaannya bisa mencapai 10 tahun.

f. Kontap Pria (Kontrasepsi Mantap) / Vasektomi

Kontrasepsi permanen laki-laki untuk mereka yang tidak menginginkan anak lagi. Dalam pelaksanaannya nanti, pemakai harus menandatangani surat persetujuan yang juga harus ditandatangani oleh istrinya.

g. Kontap Wanita (Kontrasepsi Mantap) / Tubektomi

Kontrasepsi permanen wanita untuk mereka yang tidak menginginkan anak lagi. Dalam pelaksanaannya nanti, pemakai harus menandatangani surat persetujuan yang juga harus ditandatangani oleh suaminya.

\subsection{Android}

Pencetus gagasan lahirnya Android dimulai oleh Google Inc. yang berkolaborasi dengan Android Inc. Android Inc adalah sebuah perusahaan yang berada di Palo Alto, California Amerika Serikat. Kemudian perusahaan tersebut mengembangkan dan mempercanggih sistem operasi Android, Maka dibentuklah Open Handset Alliance, Konsorsium dari 34 perusahaan diantaranya adalah Google, INTEL, HTC, Motorola, Qualcomm, T-Mobile.

\subsubsection{Versi Android}

Hendra Nugraha Lengkong (2015:20) di dalam E-journal Teknik Elektro dan Komputer menjelaskan versi-versi Android yang pernah ada, yaitu : 
a. Android versi 1.1

Pada awal tahun 2009, Google merilis Android versi 1.1. Android versi ini dilengkapi dengan beberapa fitur, Seperti Jam Alarm,r Voice Search (pencarian suara), pengiriman pesan dengan Gmail, dan pemberitahuan email.

b. Android 1.5 (Cupcake)

Pada pertengahan 2009, Google kembali merilis telepon seluler dengan menggunakan Android dan SDK ( Software Development Kit) dengan versi 1.5 (Cupcake). Pembaharuan fiturnya seperti Kemampuan merekam, dan menonton video dengan modus kamera, mengunggah video ke Youtube dan gambar ke picasa langsung dari telepon, dukungan Bluetooth A2DP, kemampuan ini terhubung secara otomatis ke headset Bluetooth, Animasi Layar, dan Keyboad pada layar yang dapat disesuaikan dengan sistem.

c. Androrid Versi 1.6 (Donut) Android Versi 1.6 (Donut) dirilis pada bulan September mengusung proses pencarian yang lebih baik dari sebelumnya. Penggunaan baterai indicator dan control applet VPN serta didukung dengan galeri yang memungkinkan pengguna untuk memilih foto yang akan dihapus, kamera, camcorder dan galeri yang diintegrasikan, CDMA/EVDO, 802.1x, VPN, Gestures, kemampuan dial kontak, pengadaan resolusi VWGA.

d. Android 2.0/2.1 Eclair

Android 2.0/2.1 Eclair Dirilis pada bulan desember 2009. Eclair adalah makanan penutup yakni kue yang biasanya berbentuk persegi panjang yang dibuat dengan krim di tengah dan lapisan cokelat di atasnya.

e. Android 2.2 Froyo

Dirilis $20 \quad$ Mei 2010. Menggunakan codename Froyo, yang merupakan makan penutup yang nama merek sebuah produk yang terbuat dari Yoghurt. Froyo singkatan dari Frozen Yoghurt, Froyo adalah yoghurt yang telah mengalami proses pendinginan,sehingga secara terlihat sama seperti es krim.

f. Android 2.3 Gingerbread

Android versi 2.3 Gingerbread dirilis resmi tanggal 6 Desember 2010. Gingerbread merupakan jenis kue kering yang dengan rasa jahe. Kue jahe biasanya dibuat 
pada perayaan hari libur akhir tahun di Amerika. Biasanya cemilan kering ini dicetak berbentuk tubuh manusia.

g. Android 3.0 Honeycomb

Dirilis tanggal 22 February 2011. $\mathrm{H}$ adalah sereal sarapan manis yang sudah dibuat oleh Posting Sereal. Seperti namanya, Honeycomb/sarang lebah, sereal ini terbuat dari potongan jagung berbentuk sarang lebah dengan rasa madu.

h. Android 4.0 Ice Cream Sandwich Android 4.0-4.0.2 API Level 14 dan 4.0.3 API Level 15 pertama dirilis 19 Oktober 2001. Dinamai Ice Cream Sandwich. Ice Cream Sandwich Es krim, biasanya rasa vanilla yang terjepit di antara dua kue coklat, dan biasanya berbentuk persegi panjang.

i. Android 4.1 Jelly bean Android Jelly Bean diluncurkan pertama kali pada Juli 2012, dengan berbasis Linux Kernel dari Android 4.1 API Level 16, Android 4.2 API Level 17 , Android 4.3 API Level 18. Penamaan mengadaptasi nama sejenis permen dalam beraneka macam rasa buah. Ukurannya sebesar kacang merah. Permen ini keras di luar tapi lunak di dalam serta lengket bila di gigit.

j. Android 4.4 KitKat

Android 4.4 Kitkat API level 19.Google mengumumkan Android KitKat (dinamai dengan izin Nestle dan Hershey) pada 3 september 2013. Dengan tanggal rilis 31 Oktober 2013. KitKat merupakan merk sebuah coklat yang dikeluarkan oleh Nestle. Rilis berikutnya setelah nama KitKat diperkirakan banyak pengamat akan diberi nomor 5.0 dan dinamai 'Pie'.

\section{METODE PENELITIAN}

\subsection{Kerangka Kerja}

Kerangka kerja merupakan langkahlangkah atau tahap untuk pelaksanaan membangun sistem yang akan dirancang.

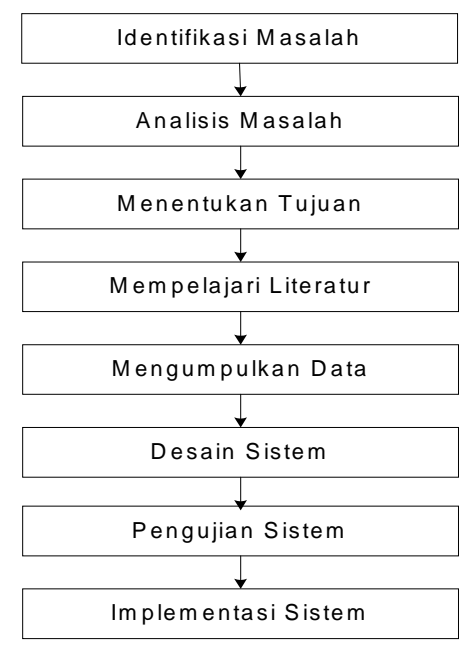

Gambar 3.1 Kerangka kerja 


\section{HASIL DAN PEMBAHASAN}

\subsection{Desain Penelitian}

Pada tahap ini adalah langkahlangkah untuk desain sistem dengan metode Backward Chaining dalam pemilihan alat kontrasepsi. Dengan menemukan berberapa fakta yang terjadi dan melakukan penelusuran belakang kedepan, sehingga pengguna (user) sistem android pada smartphone bisa mendapatkan informasi sesuai dengan kondisi pengguna alat kontrasepsi.

Tabel 4.1 Knowledge Base

Rule (IF-T HEN)

\begin{tabular}{ll}
\multicolumn{1}{c}{$\begin{array}{c}\text { Kode Alat } \\
\text { Kontrasepsi }\end{array}$} & \multicolumn{1}{c}{ Keterangan } \\
\hline A.K 01 & Kondom \\
\hline A.K 02 & Pil KB \\
\hline A.K 03 & Suntik KB \\
\hline A.K 04 & AKBK (Alat Kontrasepsi \\
& Bawah Kulit)/ Susuk \\
A.K 05 & AKDR ( Alat Kontrasepsi \\
\hline A.K 06 & Dalam Rahim). \\
\hline A.K 07 & Tusektomi (Kontap Pria) \\
\hline
\end{tabular}

Tabel 4.2 Fakta-Fakta

\begin{tabular}{ll}
\hline Kode Fakta & \multicolumn{1}{c}{ Keterangan } \\
\hline K.01 & Usia 20-35 Tahun \\
\hline K.02 & Usia 36-49 Tahun \\
\hline K.03 & Pasca Melahirkan < 3 Minggu \\
\hline K.04 & Pasca Melahirkan < 4 Minggu \\
\hline
\end{tabular}

\begin{tabular}{ll}
\hline K.05 & Pasca Melahirkan <6 Minggu \\
\hline K.06 & Menyusui < 6 Bulan \\
\hline K.07 & Hamil \\
\hline K.08 & Hipertensi \\
\hline K.09 & Stroke \\
\hline K.10 & Jantung \\
\hline K.11 & Diabetes \\
\hline K.12 & Kanker Payudara \\
\hline K.13 & Migrain \\
\hline K.14 & Mens Tidak Normal \\
\hline K.15 & Pendarahan Abnormal \\
\hline K.16 & IMS (Infeksi Menular Seksual) \\
\hline K.17 & Merokok \\
\hline K.18 & Minum Obat \\
\hline K.19 & Menunda Kehamilan \\
\hline K.20 & Memberi Jarak Kehamilan \\
\hline K.21 & Tidak Ingin Hamil Lagi \\
\hline
\end{tabular}

Tabel 4.3 Aturan

\begin{tabular}{cl}
\hline No & \multicolumn{1}{c}{ Aturan } \\
\hline 1 & IF Kondom (A.K 01) Then IMS (Infeksi \\
& Menular Seksual) (K.16) AND Menunda \\
& Kehamilan (K.19). \\
\hline 2 & IF Pil KB (A.K 02) Then Usia 20-35 \\
& Tahun (K.01) AND Pasca Melahirkan <4 \\
& Minggu (K.04) AND AKDR ( Alat \\
& Kontrasepsi Dalam Rahim) (K.05) \\
& AND Kanker Payudara (K.13) AND \\
& Menunda Kehamilan (K.19) AND \\
& Memberi Jarak Kehamilan (K.20). \\
\hline 3 & IF Suntik KB (A.K 03) Then Usia 20-35 \\
& Tahun (K.01) AND Pasca Melahirkan <3 \\
& Minggu (K.03) AND Pasca Melahirkan < \\
& 4 Minggu (K.04) AND Pasca Melahirkan \\
\hline
\end{tabular}




\begin{tabular}{|c|c|}
\hline \multicolumn{2}{|r|}{ < 6 Minggu (K.05) AND Migrain (K.13) } \\
\hline & AND IMS (Infeksi Menular Seksual) \\
\hline & (K.16) AND Minum Obat (K.18) AND \\
\hline & Menunda Kehamilan (K.19) AND \\
\hline & Memberi Jarak Kehamilan (K.20). \\
\hline \multirow[t]{12}{*}{4} & IF Susuk/AKBK (A.K 04) Then Usia 20- \\
\hline & 35 Tahun (K.01) AND Usia 36-49 Tahun \\
\hline & (K.02) AND Pasca Melahirkan < 3 \\
\hline & Minggu (K.03) AND Pasca Melahirkan < \\
\hline & 4 Minggu (K.04) AND Pasca Melahirkan \\
\hline & $<6$ Minggu (K.05) AND Menyusui < 6 \\
\hline & Bulan (K.06) AND Hipertensi (K.08) \\
\hline & AND Diabetes (K.11) AND Mens Tidak \\
\hline & Normal (K.14) AND IMS (Infeksi \\
\hline & Menular Seksual) (K.16) AND Merokok \\
\hline & (K.17) AND Memberi Jarak Kehamilan \\
\hline & (K.20). \\
\hline \multirow[t]{8}{*}{5} & IF AKDR (A.K 05) Then Usia 36-49 \\
\hline & Tahun (K.02) AND Pasca Melahirkan < 3 \\
\hline & Minggu (K.04) AND Menyusui $<6$ \\
\hline & Bulan (K.06) AND Hipertensi (K.08) \\
\hline & AND Stroke (K.09) AND Jantung (K.10) \\
\hline & AND Diabetes (K.11) AND Kanker \\
\hline & Payudara (K.12) AND Merokok (K.17) \\
\hline & AND Memberi Jarak Kehamilan (K.20). \\
\hline \multirow[t]{4}{*}{6} & IF VASEKTOMI (A.K 06) Then Usia \\
\hline & 36-49 Tahun (K.02) AND Pendarahan \\
\hline & Abnormal (K.15) AND Tidak Ingin \\
\hline & Hamil Lagi (K.21). \\
\hline \multirow[t]{5}{*}{7} & IF TUBEKTOMI (A.K 07) Then Usia \\
\hline & 36-49 Tahun (K.02) AND Pasca \\
\hline & Melahirkan < 3 Minggu (K.03) AND \\
\hline & Menyusui < 6 Bulan (K.06) AND Tidak \\
\hline & Ingin Hamil Lagi (K.21). \\
\hline
\end{tabular}

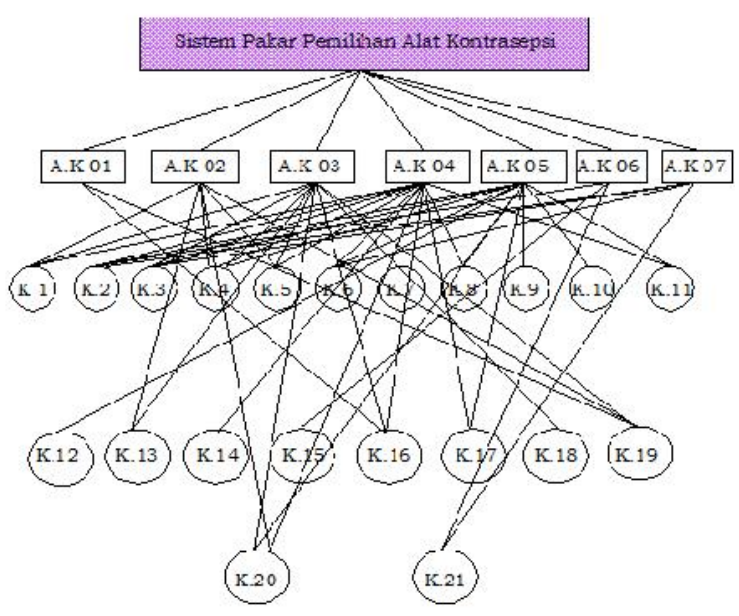

Gambar 4.1 Pohon Keputusan

\subsection{Implementasi Sistem}

\subsubsection{Menu}

Pada tampilan menu android ini akan memberikan beberapa menu pilihan yaitu konsultasi, Informasi, Jadwal Praktek Bidan dan About yang berisikan tentang informasi penting yang berhubungan dengan data perancang sistem dan lain-lain.

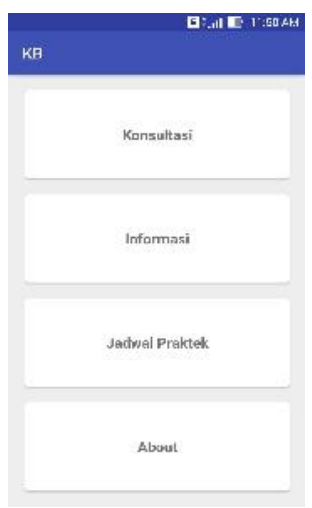

Gambar 4.2 Tampilan Menu 


\subsubsection{Halaman Konsultasi}

Halaman konsultasi ini merupakan proses eksekusi pemilihan alat Kontrasepsi yang tepat bagi pengguna sistem berdasarkan dari rule yang sudah ditentukan dan akan disimpulkan dengan menggunakan Metode Backward Chaining.

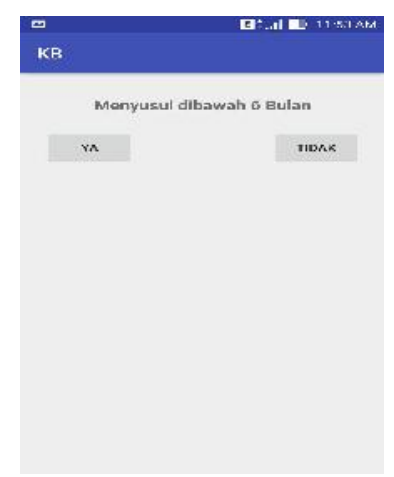

Gambar 4.3 Proses Eksekusi pada sistem

\subsubsection{Hasil Proses Eksekusi}

Hasil proses eksekusi akan memberikan jenis alat kontrasepsi yang cocok berdasarkan dari fakta-fakta yang ada.

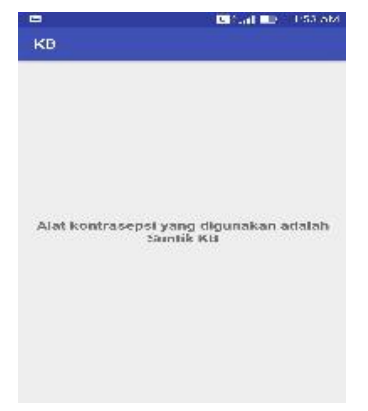

Gambar 4.4 Hasil Proses Eksekusi Informasi

Pada tampilan sistem ini akan menjelaskan tentang Keuntungan dan kekurangan pada alat kontrasepsi dengan tujuan pengguna sistem bisa mengetahui tentang alat kontrasepsi sebelum menggunakan alat kontrasepsi. Sehingga pengguna bisa memahami implementasi tentang alat kontrasepsi.

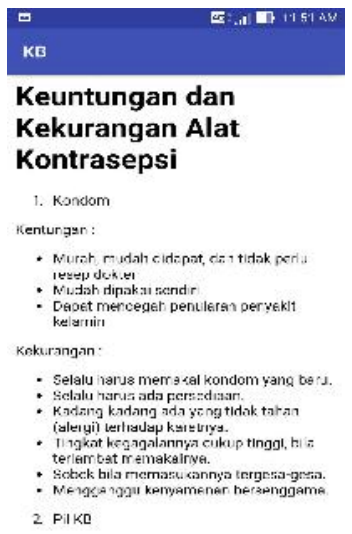

Gambar 4.5 Tampilan Keuntungan dan Kekurangan Alat Kontrasepsi

\subsubsection{About}

Berisikan tentang beberapa informasi penting tentang jadwal bidan atau dokter spesialis kandungan dan juga bisa mengetahui informasi tentang perancang sistem.

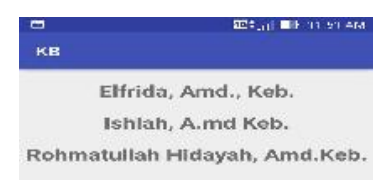

Gambar 4.6 Tampilan About 


\section{KESIMPULAN DAN SARAN}

\subsection{KESIMPULAN}

Berdasarkan dari penjelasan dan uraian perancangan sistem untuk pemilihan alat kontrasepsi yang cocok maka dapat disimpulkan bahwa :

1. Masih kurangnya sosialisasi dari petugas BKKBN untuk pemanfaatan alat kontrasepsi yang tepat dan yang baik bagi pasien.

2. Belum adanya sistem yang terintegrasi berbantuan teknologi informasi saat ini sehingga minimnya sumber daya informasi bagi masyarakat tentang alat kontrasepsi.

3. Tidak adanya penjelasan kepada masyarakat tentang keuntungan dan kerugian dalam menggunakan alat kontrasepsi berdasarkan dari beberapa kriteria kondisi kesehatan masyarakat.

\subsection{SARAN}

Adapun saran yang bisa diberikan untuk peneliti selanjutnya berdasarkan dari kesimpulan yang sudah dijelaskan. Sarannya yaitu berupa :

1. Untuk pengguna sistem diharapkan bisa menggunakan dan memanfaatkan sistem informasi dengan baik sesuai dengan kebutuhan pengguna.
2. Dengan perancangan sistem ini diharapkan kepada peneliti selanjutnya bisa lebih membangun sistem teknologi informasi lebih spesifik dan detail.

3. Dalam merancang sistem selanjutnya diharapkan bisa mendapatkan dan mengumpulkan informasi lebih banyak lagi dari beberapa pakar dibidang alat kontrasepsi.

\section{DAFTAR PUSTAKA}

Andi. (2009). Pengembangan Sistem Pakar Menggunakan Visual Basic. (2nd ed.). Yogyakarta: Andi Offset. Asabere, N. Y., \& Enguah, S. E. (2012). Integration of Expert Systems in Mobile Learning. International Journal of Information and Communication Technology Research, 2(1), 55-61.

Dahria, M. (2012). Implementasi Inferensi Backward Chaining Untuk Mengetahui Kerusakan Monitor Komputer. Saintikom, 11(73).

Fitriastuti, F., \& Ekowati, L. S. (2009). Aplikasi Sistem Pakar Berbasis Web Untuk Mendeteksi Kerusakan Perangkat Keras Komputer dengan Metode Backward Chaining. Junateknika, 11(2), 95-106. 
H.M, J. (2007). Dasar-dasar Pengetahuan Ilmu Komputer (7th ed.). Yogyakarta: Andi Offset.

Kamaludin, A. (2012). Sistem Pendukung Keputusan Dalam Pemilihan Alternatif Alat Kontrasepsi Menggunakan Simple Additive Weighting, (april).

Lesmana, L. S. (2017). Penerapan Metode Fordward Chaining untuk Mendiagnosa Gangguan Autis pada Anak Berbasis Android. Jurnal Komputer Terapan, 3(1), 19-32.

Qulsum, R., Destiani, D., Cahyana, R., Algoritma, J., Tinggi, S., Garut, T., ... Serviks, K. (n.d.). Pengembangan sistem pakar untuk diagnosa pemilihan alat kontrasepsi, 1-8.

Ramadhan, M. (2011). Sistem Pakar Dalam Mengidentifikasi Penyakit Kanker Pada Anak Sejak Dini dan Cara Penanggulangannya. Jurnal SAINTIKOM, 10(2), 125-135.

Rohman, F. F., \& Fauzijah. (2008). Rancang Bangun Aplikasi Sistem Pakar Untuk Menentukan Jenis Gangguan Perkembangan Pada Anak. Media, 6(1), 1-23.

Setyawan, I., \& Isa, M. (2013). Perancangan dan Implementasi Sistem Pakar Berbasis Android untuk Membantu Pengambilan Keputusan Dalam Menentukan Alat Kontrasepsi, l(1), 1-5.
Soepomo, P. (2013). Sistem pakar untuk mendiagnosa penyakit saluran pencernaan menggunakan metode dempster shafer 1. Jurnal Sarjana Teknik Informatika Volume 1 Nomor 1, Juni 2013 E-ISSN: 2338-5197, 1, 3241.

Soltan, R. ., Rashad, M. Z., \& El-Desouky, B. (2013). Diagnosis of Some Diseases in Medicine via computerized Experts System. International Journal of Computer Science and Information Technology, $5(5)$, 79-90. https://doi.org/10.5121/ijcsit.2013.55 05

Suci Oktaviana, Satria Perdana Arifin, S.T, M.T.I, Ibnu Surya, S. . (2012). Sistem Pakar Diagnosa Penyakit Ginjal Menggunakan Metode Hill Climbing. Jurnal Teknik Informatika, 1, 1-10.

Tentua, M. N. (2010). Sistem Pakar Untuk Menentukan Alat Kontrasepsi Bagi Pasangan Menikah. Dinamika Komputer, 4(September), 111-122. 